\title{
Analysis of Stocks Return, Internal Factors, and Macroeconomics for Investor's Decision Making
}

\author{
Ghina Salsabila ${ }^{1}$, Endang Chumaidiyah ${ }^{2}$, Rita Zulbetti $^{3}$ \\ Industrial Engineering Department, Telkom University, Bandung, Indonesia
}

ghinasalsabila@student.telkomuniversity.ac.id ${ }^{1}$,endangcn@gmail.com² ${ }^{2}$ zulbetti@gmail.com³

\begin{abstract}
Building construction companies placed on the top three, the most significant business field contributes to GDP (Gross Domestic Product) in Indonesia, with an annual average of 12 percent. This study aims to determine the effect of internal factors and macroeconomics simultaneously and partially on stock return at building construction companies. Variables of internal factors are EPS (Earning Per Share), DER (Debt to Equity Ratio), and ROE (Return on Equity), while variables of macroeconomics are BI Rate, inflation, and economic growth. This research purpose is to help investor's decision making of stock return. The data type used are secondary data, time series, and crosssection by using data panel regression with a linear output regression. The sample used is seven-building construction companies listed in IDX (Indonesia Stock Exchange) during the period 2014-2019. This research found inflation is a variable that has simultaneously and partially affected on the stock return. Decision-makers should consider inflation toward improves the performance of building construction companies.
\end{abstract}

Keywords: Stock Return, Decision Making, Internal Factors, Macroeconomics

\section{Introduction}

The Government of Indonesia issued four points on the Major Development Project of the Java-Bali Region, the contents of the 4th point are the Major Projects for the Moving of the Capital of the State out of Java, which has benefits for equitable development and improving inter-regional welfare starting from 2020 to 2024, with the estimated total allocation of funds needed is 83.8 trillion rupiahs. Some major project implementers are the Ministry of National Development Planning and the Ministry of Public Works and Housing [1]. Seeing this, building construction companies is certainly a good investment potential. Plus, building construction companies are placed on the top three, the most significant business field contributing to GDP (Gross Domestic Product) in Indonesia, with an annual average of 12 percent [2].

A country's investment is influenced by several macroeconomic factors including GDP (Gross Domestic Product) growth rates, inflation growth rates, and the money supply [3]. Thus, the macroeconomics factor is closely related to investment in building construction companies. In addition to external or macroeconomic factors, the internal factors as financial statements explaining how a company run [4]. Seven-building construction companies sample listed in IDX (Indonesia Stock Exchange), informed that the number of equity of companies has increased over the study period from 2014 to 2019.

This research was conducted to determine what variables are needed by the investor to make investment decisions in building construction companies, both in terms of internal factors and macroeconomics. Besides, this research also helps decision-makers of building construction companies improve their performance. 


\section{Research Methodology}

\subsection{Research Purpose}

This study aims to determine the effect of independent variables are internal factors [EPS (Earning Per Share), DER (Debt to Equity Ratio), and ROE (Return on Equity)] and macroeconomics (BI Rate, inflation, and economic growth) simultaneously and partially on the dependent variable is the stock return at building construction companies. This research purpose is to help investor's decision-making of stock return at building construction companies. Besides, this research also helps decision-makers of building construction companies improve their performance.

\subsection{Problem}

Decision-makers and investors do not know what variables that have a significant and partial effect on stock return should be considered for decision-making.

\subsection{Research Framework Model}

This research builds on three internal factors and three macroeconomics factors. This study aims to determine the effect of independent variables consisting of code X1 for ROE, code X2 for DER, code X3 for EPS, code X4 for BI Rate, code X5 for inflation, and code X6 for economic growth. The dependent variable in the form of stocks return with code Y. Then, stocks return will be analyzed to help investor's decision-making of stock return at building construction, and companies decision-makers can evaluate and improve company performance better.

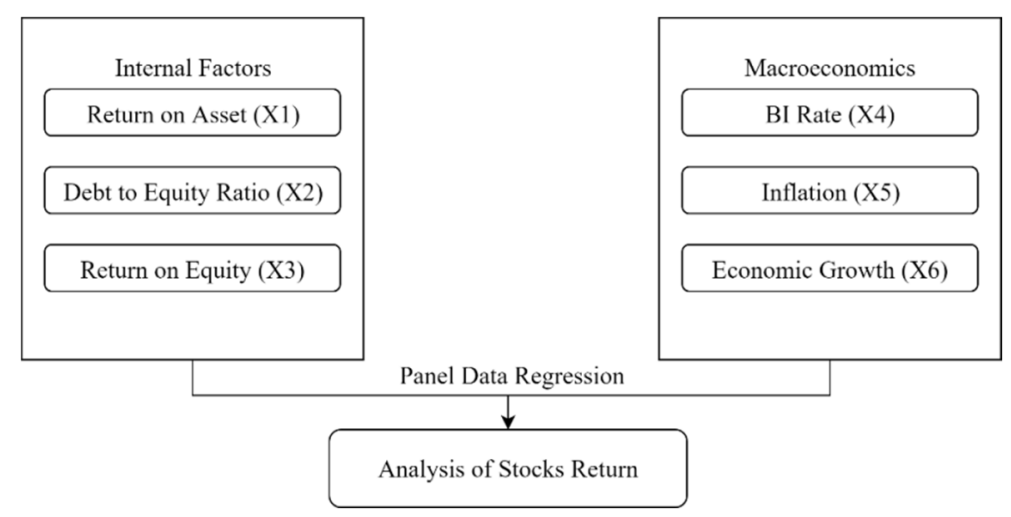

Fig. 1. Conceptual Model

\subsection{Data Testing}

Data obtained is tested by model estimation, normality, autocorrelation, multicollinearity, and heteroskedasticity [5].

Hypothesis on F Test (Simultaneous) Test:

$\mathrm{H}_{0 \mathrm{a}}=\mathrm{EPS}$, DER, ROE, BI Rate, inflation, and economic growth simultaneously do not 
have a significant effect on stocks return in the building construction subsector listed on the Indonesia Stock Exchange.

$\mathrm{H}_{1 \mathrm{a}}=$ EPS, DER, ROE, BI Rate, inflation, and economic growth simultaneously have a significant effect on stocks return in the building construction subsector listed on the Indonesia Stock Exchange.

Hypothesis on T Test (Partial) Test:

$\mathrm{H}_{0 b}=\mathrm{X}$ variable partially does not have a significant effect on stocks return in the building construction subsector listed on the Indonesia Stock Exchange.

$\mathrm{H} 1 \mathrm{~b}=\mathrm{X}$ variable partially has a significant effect on stocks return in the building construction subsector listed on the Indonesia Stock Exchange.

\subsection{Panel Data Regression}

Based on the results of the $\mathrm{F}$ test and $\mathrm{T}$ test, this study can determine the panel data regression model that represents the correlation between the independent variables and the dependent variable. $T$ test results are used to produce independent variables that have a significant effect on stock returns. Only variables that have a significant effect are included in the panel data regression model. In this study, the regression model that will be used is as follows [6]:

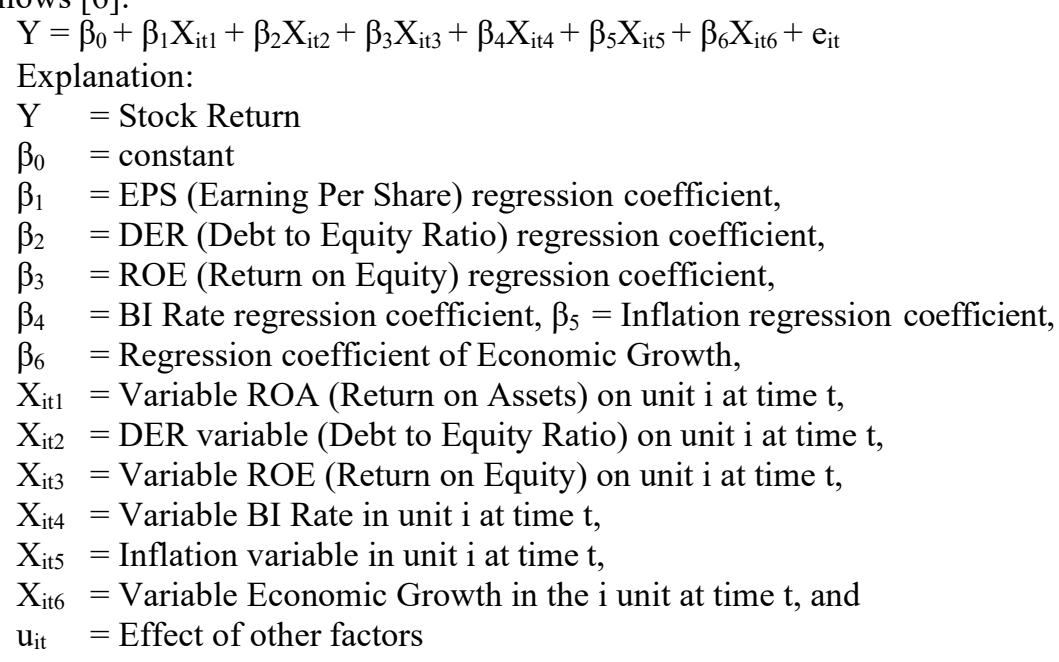

\subsection{Data Source}

The data needed for this research is secondary data obtained from IDX Annual (4 $4^{\text {th }}$ Quarter) Statistics 2012-2019 and Central Bureau of Statistics Republic of Indonesia.

\subsection{Data Processing}

EViews 10 and IBM SPSS Statistics 26 for Windows 10 Home Single Language 64-bit operating system is used to perform the regression test.

\subsection{Previous Study}

There is previous research that discusses: 
1. The effect of EPS, ROE, DER, dollar exchange rate, and inflation toward stocks return at the transportation subsector in Indonesia Stock Exchange 2012-2017. This research found that inflation simultaneously and partially affects the stock return [7].

2. The effect of EPS, DER, ROA, inflation, and dollar exchange rate toward stocks return at the pharmaceutical subsector in Indonesia Stock Exchange 2010-2016. This research found that EPS and dollar exchange simultaneously and partially affect the stock return [8].

3. The effect of EPS, DER, ROA, PER, inflation, and BI rate toward stocks return at the telecommunication subsector in Indonesia Stock Exchange 2007-2015. This research found that ROA and inflation simultaneously and partially affect the stock return [9].

4. The effect of EPS value before and after companies perform IPO in Indonesia Stock Exchange 2013. This research found that EPS value before and after IPO in the sector of manufacture; trade, services, and investment; infrastructure and property have no significant differences in average [10].

\section{Result and Analysis}

\subsection{F Test and T Test}

Table 1. $F$ Test and $T$ Test

\begin{tabular}{ccc}
\hline \multicolumn{3}{c}{ Prob(F-statistic) $=\mathbf{0 . 0 0 0 0 0 0}$} \\
\hline EPS & Prob $>|t|$ & 0,0985 \\
DER & Prob $>|t|$ & 0,0789 \\
ROE & Prob $>|t|$ & 0,0525 \\
BI Rate & Prob $>|t|$ & 0,4135 \\
Inflation & Prob $>|t|$ & 0.0001 \\
Economic Growth & Prob $>|t|$ & 0.1071 \\
\hline
\end{tabular}

Based on the results of the $\mathrm{F}$ test and $\mathrm{T}$ test in Table 1, it can be interpreted by the $\mathrm{F}$ test $($ Prob $>$ F $)=0.000000$ as EPS, DER, ROE, macroeconomic, BI Rate, inflation, and economic growth simultaneously affects stock return as $\mathrm{H}_{1 \mathrm{a}}$ is accepted and $\mathrm{H}_{0 \mathrm{a}}$ is rejected. While inflation with probability values of 0.0001 is the result of $F$ test with (Prob $>t$ ) consisted of less than the significance of 5 percent, indicates that inflation has a simultaneous and partial effect on stocks return as $\mathrm{H}_{1 \mathrm{~b}}$ is accepted and $\mathrm{H}_{0 \mathrm{~b}}$ is rejected.

\subsection{Analysis of Panel Data Regression}

The formulation of inflation that has a significant effect on stocks return: $\mathrm{Y}=-958.4469+21.78155$ Inflation $+\mathrm{e}_{\mathrm{it}}$

Explanation:

a) Constanta of -958.4469 indicates that if the value of inflation is zero, then stocks return will be predicted at -958.4469 .

b) Inflation with a positive coefficient of 21.78155 indicates that every 100 percent increase in inflation predicted to be able to increase stock returns by 21.78155 , with the condition in other variables is assumed to be constant. 


\section{Conclusion}

The results of the study above show that internal factors and macroeconomics variables that have a simultaneous effect on the return of the stock are EPS, DER, ROE, BI Rate, and inflation with the value of Prob(F-statistic) $=0.000000$. While the result of the analysis of panel data regression shows that inflation with probability values of 0.0001 is the result of $F$ test with $($ Prob $>\mathrm{t})$ consisted of less than the significance of 5 percent, is simultaneously and partially effects on the stocks return; every 100 percent increase in inflation predicted to be able to increase stock returns by 21.78155 with the condition in other variables is assumed to be constant. Decision-makers should consider the variable of inflation to improve the performance of building construction companies. While investor should consider inflation to get a significant capital gain in stock return when investing in the stock of building construction companies.

\section{References}

[1] Bappenas: Rencana Pembangunan Jangka Menengah Nasional IV Periode 2020-2024. Indonesian Ministry of National Development Planning, Indonesia (2019)

[2] Central Bureau of Statistics Republic of Indonesia: Official Statistics News, Indonesia (20132019)

[3] Tandelilin, E.: Pasar Modal: Manajemen Portofolio dan Investasi. Kanisius, Indonesia (2017)

[4] Pidada, I. B. S.; Yuesti, A.; and Kepramareni, P.: The Influence of Internal and External Factors with Risk Factors as Mediation Variable to Financial Performance of Regional Development Bank in Indonesia. International Journal of Contemporary Research and Review. Vol. 9, pp. 20533-20543(2018)

[5] Prasanti, T. A.; Wuryandari, T.; and Rusgiyono, A.: Aplikasi Regresi Data Panel untuk Pemodelan Tingkat Pengangguran Terbuka Kabupaten/Kota di Provinsi Jawa Tengah. Jurnal Gaussian. Vol. 4, pp. 687-696 (2015)

[6] Arifianto, D.: Ekonometrika Esensi dan Aplikasi dengan Menggunakan EVIEWS. Erlangga, Indonesia (2012)

[7] Nurindahsari, D. A.; Chumaidiyah, E.; and Suryana, N.: Analisis Pengaruh EPS, ROE, DER, Kurs, dan Inflasi terhadap Return Saham Sub Sektor Transportasi Periode 2012-2017. Jurnal Mitra Manajemen. Vol. 3, No. 7, pp. 743-754 (2019)

[8] Septian, N.; Chumaidiyah, E.; and Zulbetti, R.: Company Strategy Based on Linier Regression of Stocks Return to the EPS and Dollar Exchange at Pharmaceutical Industry in Indonesia Stock Exchange 2010-2016. Atlantis Highlights in Engineering (AHE). Vol. 2, pp. 314-319 (2018)

[9] Pratiwi D.; Chumaidiyah E.; and Zulbetti R.: Strategi Perusahaan Berdasarkan Analisis Return Saham terhadap EPS, DER, ROA, PER, Inflasi, dan BI Rate Pada Sub Sektor Telekomunikasi di Bursa Efek Indonesia 2007-2015. Jurnal Teknik Industri. Vol. 7, No. 2, pp. 87-93 (2017)

[10] Putri D. A. J.; Chumaidiyah E.; and Zulbetti R.: Analysis of Earnings Per Share Before and After IPO and the Strategy (Case Study: Companies Perform IPO in Indonesia Stock Exchange Year 2013). Proceeding of 9th International Seminar on Industrial Engineering and Management. Vol. 9, pp. 73-84 (2016)

[11] Ghozali, I.: Aplikasi Analisis Multivariat dengan Program IBM SPSS 20. Badan Penerbit Universitas Diponegoro, Indonesia (2011) 